\title{
Study on Ashoka and Akbar's Influence by Comparing the Maurya Dynasty and the Mughal Dynasty
}

\author{
Ping Ni \\ School of Foreign Language, Lanzhou University, Lanzhou 730030, Gansu, China \\ Email: 13649585923@163.com
}

\begin{abstract}
It is recognized that the history of a nation is not only the study of the dynamics of dynasties represented by individual rulers but the study of social and economic aspects of different rural and urban, religious groups of the Hindus, the Buddhists and the Muslims, customs and traditions, living standard and style of the agricultural and mercantile occupations, and artisans and craftsmen of different professions as a whole. This thesis would focus on the regulations and religions to study the influence of the great kings in India, especially the Akbar the Great who led the Mughal Dynasty to prosperity and the Ashoka the Great who not only led the Maurya Dynasty to prosperity, but also promoted the Buddhism all over the world.
\end{abstract}

Keywords: India, Akbar the Great, Ashoka the Great, Buddhism

\section{The Maurya Dynasty}

\subsection{The introduction of the Maurya Dynasty}

Maurya Dynasty (c.324-185 BCE) is a famous slavery dynasty in Magadha Kingdom of ancient India. The dynasty was named after the founder who was from a family, the Mauryas.

Chandragupta Maurya was the founder of the Maurya Dynasty, and he fought against the remain power in Punjab left by Hellene, and conquered most areas in Northern India. Besides, Chandragupta Maurya also beat the aggression of Seleucid Dynasty during his upper regulation, and obtained the dominion over Afghan. In 300 BC, Maurya Dynasty under the regulation of Ashoka was unprecedentedly powerful and prosperous. At the same time, the Buddhism was spread outward. After the death of Ashoka, his son stayed in a region, and Maurya Dynasty has been regulated for about 50 years.

\subsection{The emperors of the Maurya Dynasty}

Chandragupta Maurya was the first king of the Maurya Dynasty. He fought against the aggression of Hellene, avoiding India to become a subject country of Hellene. He believed in Jainism, which was similar to Buddhism. He believed in "Soul Liberation, Karma Reincarnation", and advocated "No Violence, No Killing and Practice Mercy". However, Jainism promoted strict abstinency and austerity, so the first king of Maurya Dynasty abandoned his kingship, went to the forest when he was old, and died of Hunger Strike at last.

Bindusara was the second king of Maurya Dynasty. He inherited his father's expansion policy, and added more land to his Dynasty. As for the diplomacy, he maintained good relationship with many Hellenistic States.

Ashoka was the son of Bindusara, and he was the most famous king of Maurya Dynasty. The following thesis will give a specific introduction about Ashoka.

In about 185 BC, the last king Brihadratha (c.187-185 BCE) of the Maurya Dynasty was killed by the minister Pushyamitra Shunga (the founder of the Sunga Dynasty). This is the end of the Maurya Dynasty, and it was also the first unified regime in ancient India.

\subsection{Ashoka the Great}

\subsubsection{The introduction of Ashoka}

Ashoka inherited an already sizeable kindom in north-eastern India from his father, Bindusara (c.298-270 BCE), and his grandfather, dynastic founder Chandragupta Maurya (c.322-298 BCE). He was the third but the most powerful of the Mauryan emperors who once dominated the Indian subcontinent from 268 BC to 232 BC and also played a very important role in the spread of Buddhism. Ashoka was one of the greatest Kings in the history of India. He extended Pantragupta Maurya's dominion from western Afghanistan to eastern Bangladesh. The territory covers all of today's Indian subcontinent except the modern Tamil Nadu, southern Karnataka, Assam and Bangladesh, and he pushed its borders northwest into what 
is now eastern Afghanistan. During the period of Ashoka, the capital of the Maurya kingdom was Fahrenheit city, which is now Batna.

Ashoka waged a bloody war against Kalinga (which is Now Orissa) and conquered it in 260 BC. After witnessing the horrors of the Battle of Kalinga, Ashoka became a Buddhist in $263 \mathrm{BC}$. Ashoka was known for his pillars, his imperial edicts, and the propagandists he sent to Sri Lanka and Central Asia. In addition, Ashoka erected monuments in several places where Sakyamuni lived and preached before Nirvana.

\subsubsection{Wise ruler}

Based on the spirit of Buddhism, Ashoka ruled the country by peace. This thought was not a dream, but under the basis of reality. Though Ashoka banned killing, he did not abolish death penalty. Though Ashoka was a pious Buddhist, he was tolerant with other religions, and allowed the existence of other religion. Ashoka established a system of government by one person with absolue power, and set up a highly centralized country.

\subsubsection{Ashoka and Buddhism (religion)}

Ashoka had five wives, four sons and two daughters. Throughout his life, the scholars divided it into two parts - bad Ashoka and good Askoa. At the first period of his life, in order to be the successor of the Maurya Dynasty, he launched many bloody events to his brothers. It is said that he killed 99 brothers but only left the youngest one. After 4 years of his ruling, he was anointed and had the enthronement ceremony. Then he even set up disgusting "heaven and hell" to punish people which made the people in great fear. He expanded his territory by engaging many wars, so as to pursue united country in India. After the war against Kalingas, where over one hundred thousand people were killed and even more were wounded or taken captive and deported, Ashoka showed such deep remorse, that he decided to fully embrace Buddhism and to forswear forever the wars of aggression. In its place he established his vision of "conquering of rightousness", the victory of "Dharma". Dharma as Buddha's Dhamma: the system of the universal laws of life by humaneness and righteousness, the basis of any religion. It is the transformation to change him a "good Askoa". It is certain that at last after the 8th year of this reign, Ashoka gained support from the teachings and practices of the Buddha's followers. He sent many people to preach Buddhism, even his son Mahindra and his daughter Sanghamitra, who brought Buddhism to Sri Lanka, so as to not only spread mercy all over South East India, but also achieve his bloodless cultural conquering. Ashoka's support for Buddhism gave him a wide influence on the world. At the time of his accession, Buddhism was still a small religion in northwestern India. By the time of his death, Buddhism had spread throughout India and into neighboring regions. Besides Gautama, Ashoka was the first to develop Buddhism into a world religion. And the later legendary accounts celebrate Ashoka primarily as a paradigmatic supporter of Buddhist monks and institutions. Though the Mauryan Dynasty did not long outlast Ashoka himself, his hope that his "sons, grandsons will increase his practice of Dharma until the end of a universal aeon" did come true in the several additional ways, and Ashoka's life and deed remained foundational for subsequent South Asian and Buddhist political and religious history.

\subsubsection{Ashoka's influence around the world}

During Ashoka's regime, Sakyamuni has created Buddhism for 300 years, and Buddhism has held two Buddhist assembly. Ashoka held the third Buddhist assembly to settle the Buddhist Sutras. Besides, he cultivated generosity to people and erected edicts and pillars scripted with Buddhist Sutras to promote Buddhism. This remaining heritage also provided important data for studying ancient Buddhism. These contents not only showed the basic spirit of Buddhism, but also contained Ashoka's ruling demand.

Ashoka donated land for Buddhism to build Buddhist buildings, and sent many people to different countries to preach Buddhism, such as Sri Lanka, Burma, Syria and Egypt. This was a chance for Buddhism to become a worldwide religion. Ashoka even visited pagodas in other countries by himself.

Even in China, we have 19 towers collecting relics, and there is a exhibition hall showing the map of these 19 towers in Famen Temple Muesum. We also had Fa Yuan Zhu Lin (Tang Dynasty) to record these 19 towers. And the most famous towers is the tower named "Ashoka" in Ningbo, Zhejiang Province. There are still many visitors there to enjoy the tranquility of the Buddhism till now.

In July, 2008, the the Qibao Ashoka Tower was explored in Nanjing, Jiangsu Province, which was the biggest Ashoka Tower in China even in the world. In 12th June,2010, 108 hierarches witnessed the opening of the golden and sliver tomb of the Qibao Ashoka Tower, the Buddha's top bone relic attracted people's attention. According to evidence, there were precious Buddhist treasure, such as Buddha's top bone relic and ten inducting relics, in these two sets of the tombs. 


\section{The Mughal Dynasty}

\subsection{The introduction of the Mughal Dynasty}

The Mughal Dynasty in India lasted from 1526 to 1858 . Muslim rulers who came from the present day Uzbekistan established the Mughal dynasty. The Maurya Dynasty and the Mughal dynasty are the only two dynasties saw the country being united as one single unit and being administered under one single powerful ruler. During the period of the Mughal Dyansty, art and architecture flourished and many beautiful monuments were constructed. The rulers were not only skillful warriors, but also admirers of art.

The Mughal maintained the largest standing army of that time. The Mughal Dynasty depended on its military conquest, so many historians named this dynasty "a war state" (J F Richards). The emperors always attacked the neighbouring rulers to expand his territory.

\subsection{The emperors of the Mughal Dynasty}

There are seventeen emperors in this period, among which there are six famous emperors, including Barbur, Humayun, Akbar, Jahangir, Shah Jahan and Aurangzeb. Barbur was known as the founder of Mughal Dynasty in India. And likewise to the Maurya Dynasty, the third emperor Akbar achieved the union of the India. Consequently, Akbar was also be called the Akbar the Great. And some of his personal qualities and virtues later served as a model for his successors. Another famous emperor is Shah Jahan, it is said that during the reign of the Shah Jahan, the Mughal Dynasty prosperous greatly like never before, and the famous TAJ Mahal was built by him in memory of his one and only wife. In 1657, Shah Jahan was badly sick, and his four sons fought against each other for the throne. At last the third son Aurangzeb won this "throne fight", but he was a warlike emperor and launched many wars which widened the gap between the people and the government though do expanded the land of the Mughal Dynasty. This period is the transition made the prosperous Dynasty a waning Dynasty.

\subsection{Akbar the Great}

As the third emperor of the Mughal Dynasty, Akbar was the first emperor who integrated the whole India during the Mughal Dynasty, so as to achieve his father and his grandfather's dream of unification. It was only 13 years old when Akbar first became the successor of the throne. Without too much education, he began to govern his country under the help of the Gen. Bayram khan. At the suggestion of this general, Akbar decided to fight against Afghanistan noble to recapture the capital Delhi. It was 18 years old when Akbar could regulate the country on his own. Expanding the territory, then he adopted different policies to regulate the different land. As for the people who could come over and pledge allegiance, he agreed both their regulation and their offspring's regulation. It has been 15 years since he integrated the northern India, then he conquered the southern India within 3 years.

In order to consolidate his power, he reformed the internal affairs. He entrusted officials to remeasured the land and divided the dynasty into 182 tax zones according to which people were strictly taxed in different levels. He also initiated and established most administrative institutions to consolidate the governance. He could build a centralized administration which was capable of steady expansion as new territories were added to the dynasty. All of the functions such as diplomacy and external affairs were kept under the emperor's control. What's more, the Mughal civil and administrative officials were regulated and organized under the official system. Akbar abolished the practice of selling prisoners of war as slaves, and abolished the poll tax and the pilgrim's tax (on pilgrimages), additional taxes on land. Once met the natural or man-made disasters, people will be exempted from paying land taxes. Besides the tax, Akbar unified the national measure of weights and length, which effectively promoted the development of industry and commerce. Akbar believes in Islam, while Hinduism has long been popular in India. There were too many conflicts between Hinduism and Islam, which greatly affects the stability and unity of the country. To coordinate the relationship between Hinduism and Muslims, Akbar himself adopted a series of measures, and he announced that all the religions are equal. Besides, he designated the people who believed in Hinduism as senior officers. Akbar also practiced Hinduism in the court. Out of his 'tolerant and generous personality' and his "pursuit of religious thought", Akbar also created a "holy religion" without God, prophet and religious affairs.

Akbar died in October 1605. after his death. He laid a solid foundation for the prosperity and development of the Mughal Dynasty, and he was one of its most famous figures.

\section{Conclusion}

India is a country with many religion. To study India, we must study religion first. By comparing this two kings in India, we know that they were both great kings and made wonderful contribution to the unification of India. However, because of the mystery and myth of the religion, Akbar was just the the King of Peace, while Ashoka was the king with unique 
and legendary experience, from the wild prince to the wise ruler and to the world's great teacher. His humanistic ethical approach, as known in the edicts, was something very much in line with his ideology. Needless to say that Ashoka became beloved role model for many a teacher.

Actually, without Ashoka, Buddhism would not have become widely spread. From a small sect, split up in even smaller ones, it could grow into a world religion and so he has kept Buddha's enlightenment aflame for the seekers of today. Whatever the true purpose of Ashoka's spreading Buddhism is, through the publicity of it, Ashoka not only purified his fame, and achieved his regulation, but also made Buddhism be spread all over the world. It is Ashoka's great contribution to the world, and no one can be compared with Ashoka.

\section{References}

[1] Wytze Keuning. Ashoka the Great. Translated by J.E.Steur. New Delhi: Rupa Publications India Pvt. Ltd.; 2010.

[2] Vincent Arthur Smith. Ashoka - The Buddhist Emperor of India. Translated by Gao Yinghui. Beijing: Sino-culture Press; 2019.

[3] Mao Shichang, Liu Xuelan. The mainstream of the splendid Indian culture - Hinduism. Beijing: China Social Sciences Press; 2011.

[4] Lin Tai. General History of Great Nations - General History of India. Shanghai: Shanghai Academy of Social Sciences Press; 2007. 